\title{
Sistem Penunjang Keputusan Sistem Operasi Untuk Layanan E-Mail Server Dengan Pendekatan Analytical Heirarchy Process (AHP)
}

\author{
Ita Erliyani*1, Siti Maesaroh ${ }^{2}$, Widiya Sapitri ${ }^{3}$ \\ ${ }^{1,2,3}$ Program Studi Sistem Informasi Fakultas Sains dan Teknologi Universitas Raharja \\ E-mail : *1ita.erliyani@ raharja.info, ${ }^{2}$ siti.maesaroh@ raharja.info, \\ ${ }^{3}$ widiya.sapitri@raharja.info
}

\begin{abstract}
Abstrak
Di dalam dunia teknologi IT sangat berkembang dengan pesat, dengan pesat nya perkembangan tersebut perusahaan-perusahaan khusus yang bergerak didalam pengadaan bandwitch harus selalu melakukan pencarian-pencarian tentang teknologi IT di bidang layanan jaringan. Dan Arus pertukaran data atau informasi yang sangat dibutuhankan terus meningkat, salah satunya melalui E-mail. Pada perusahaan - perusahaan kecil yang tidak memiliki server email ataupun backup server email sendiri mereka mencari jasa layanan kepada perusahaan jasa layanan hosting, jaringan ataupun perusahaan yang bergerak dalam layanan data. Oleh karena itu PT NAP Info Lintas nusa berkeinginan untuk meningkatkan layanan dengan menambahkan pelayanan baru yaitu layanan Email server. Layanan ini diperuntukan bagi perusahaan yang belum memiliki email server sendiri ataupun perusahaan yang ingin membackup up email mereka. Dalam hal ini PT NAP Info Lintas nusa belum memiliki kriteria khusus untuk menentukan sistem operasi apa yang akan digunakan yang dapat mendukung jalannya layanan tersebut. Maka perusahaan memutuskan untuk menggunakan metode AHP dengan expert choice untuk menentukan kriteria-kriteria apa yang akan dipilih sehingga dapat menentukan alternatif yang akan dipilih.
\end{abstract}

Kata Kunci-Expert Choice, AHP, Pemilihan Sistem Operasi

\begin{abstract}
In the world of IT technology is growing rapidly, with the rapid development of these specialized companies engaged in the procurement of bandwidth must always conduct searches about IT technology in the field of network services. And the flow of highly needed data or information exchange continues to increase, one of which is via e-mail. In small companies that do not have their own e-mail server or email server backup, they look for services to hosting, network or service companies engaged in data services. Therefore PT NAP Info Lintas Nusa wishes to improve services by adding new services, namely the Email server service. This service is intended for companies that do not have their own e-mail server or companies that want to back up their e-mail. In this case PT NAP Info Lintas Nusa does not yet have specific criteria to determine what operating system will be used that can support the running of the service. So the company decided to use the AHP method with expert choice to determine what criteria would be chosen so as to determine the alternative to be chosen.
\end{abstract}

Keywords-Expert Choice, AHP, Operating System Selection 


\section{PENDAHULUAN}

Dengan perkembangan teknologi informasi saat ini, kebutuhan perusahaan akan management system informasi menyebabkan banyak perusahaan yang menggunakan teknologi informasi. PT NAP INFO LINTAS NUSA merupakan perusahaan yang bergerak di bidang Internet Service Provider ( ISP ) yang melakukan pelayanan collocation, service internet, dll. PT NAP Info Lintas Nusa adalah operator titik akses jaringan di Indonesia yang menggunakan Teknologi MPLS yang menciptakan solusi yang secara berkesinambungan menyatukan pengaturan $I P$ routing.

Dengan semakin pesatnya perkembangan perusahaan, customer yang semakin meningkat, jenis layanan yang semakin beragam dan penggunaan peralatan teknologi IT yang semakin canggih. Manajemen PT NAP INFO LINTAS NUSA ingin menambahkan pelayanan dalam email server untuk customer yang tidak memiliki e-mail server sendiri atau pun untuk backup e-mail server. Dengan penambahan layanan tersebut perusahaan harus merencanakan pembelian server dan sistem operasi yang akan digunakan dalam e-mail server untuk customer.

Perusahaan harus melakukan pengadaan sistem operasi yang sesuai dengan kebutuhan yang akan dijalankan untuk layanan tersebut. Bagian operasional khususnya kepala bagian operasional menginginkan sistem operasi yang memiliki biaya rendah, stabilitas yang baik, security sistem yang sangat baik. Dengan banyaknya sistem operasi yang beredar dipasaran dan tidak adanya kriteria yang tepat untuk membuat keputusan membuat bagian operasional khususnya kepala bagian operasional sulit menentukan sistem operasi yang tepat untuk email server customer. Maka hal yang harus dilakukan oleh Bagian operasional adalah menentukan sistem operasi yang akan dijadikan alternatif untuk layanan E-mail server.

Oleh karena itu, dalam penulisan ini peneliti mencoba membahas tentang manfaat teknologi informasi untuk mengatasi masalah yang muncul dalam pengambilan keputusan yang dihadapi oleh bagian operasional dalam menentukan sistem operasi yang tepat untuk e-mail server.

\subsection{Literature Review}

Berikut ini adalah beberapa literatur perbandingan pembahasan yang digunakan dalam penelitian ini :

a. Penelitian yang dilakukan oleh Sarwindah, dan Elly Yanuarti dari STMIK Atma Luhur ,Indonesia pada tahun 2018 yang berjudul "Sistem Penunjang Keputusan Pemilihan Perumahan Subsidi Berdasarkan Kebutuhan Konsumen dengan metode AHP". Penelitian ini menjelaskan sebuah solusi Analytical Hierarki Process dalam membantu membuat keputusan,sehingga decision maker dapat mengambil keputusan tentang perumahan sesuai yang diinginkan secara cepat dengan membandingkan semua kriteria.

b. Penelitian yang dilakukan oleh Rusydi Umar, Abdul Fadlil dan Yuminah dari Universitas Ahmad Dahlan, Yogyakarta pada tahun 2018 yang berjudul "Sistem Pendukung Keputusan dengan Metode AHP untuk Penilaian Kompetensi Soft Skill Karyawan”. Penelitian ini menjelaskan penilaian kompetensi soft skill karyawan dengan analisis data menerapkan metode Analytical Hierarchical Process yang memungkinkan perhitungan matematis dengan berbagai kriteria.

c. Penelitian yang dilakukan oleh Karmila Yusnitha, Tursina, dan Muhammad Azhar Irwansyah dari Universitas Tanjungpura, Indonesia pada tahun 2019 yang berjudul "Sistem Pendukung Keputusan Pemilihan Wilayah Prioritas Intervensi Kegiatan Keluarga Berencana dengan Metode AHP-SMART". Penelitian ini menjelaskan Aplikasi yang dibangun menggunakan metode $A H P$-SMART dengan hasil dari aplikasi ini adalah urutan nilai prefensi dari nilai terbesar hingga terkecil berdasarkan alternatif yang menjadi pilihan. 
d. Penelitian yang dilakukan oleh Eko Harli dari Universitas Indraprasta PGRI, Indonesia pada tahun 2016 yang berjudul "Pemilihan Network Monitoring System Berdasarkan Kajian Efektifitas Sistem Informasi dengan Pendekatan AHP: Studi Kasus pada PT.TUV". Penelitian ini menghasilkan metode yang tepat dalam menentukan perangkat lunak NMS berdasarkan efektivitas Sistem Informasi yang handal untuk digunakan sebagai tool monitoring jaringan, server, dan aplikasi untuk digunakan pada PT.TUV.

e. Penelitian yang dilakukan oleh Yogi Prihartono dan Hilyah Magdalena dari STMIK Atma Luhur Pangkalpinang, Indonesia pada tahun 2016 yang berjudul "Penerapan Metode Analytical Hierarchy Process (AHP) Sebagai Pendukung Keputusan dalam Menentukan Internet Service Provider Terbaik di Pangkalpinang". Penelitian ini menghasilkan Hasil pengolahan data dengan Expert Choice 2000 menunjukkan perbandingan berpasangan yang diberikan responden ahli memiliki nilai rasio inkonsistensi yang lebih kecil dari 0,1 sebagai batas maksimum nilai rasio inkonsistensi.

f. Penelitian yang dilakukan oleh Evaristus Didik Madyatmadja dari Bina Nusantara University, Jakarta, Indonesia pada tahun 2014 yang berjudul "Decision Support System Model To Assist Management Consultant In Determining The Physical Infrastructure Fund". Penelitian ini menunjukkan bahwa sistem penunjang keputusan alokasi dana untuk proyek fisik akan membantu manajemen PNPM dalam membuat, menghapus, atau mengedit model penilaian yang ada. Dengan kemudahan membuat model, manajemen PNPM dapat memahami model yang paling tepat untuk diterapkan dalam proyek fisik, sehingga alokasi untuk dana proyek fisik benar-benar diperoleh oleh kelompok sosial yang membutuhkannya.

g. Penelitian yang dilakukan oleh Maria Rashidi, Bijan Samali \&Pezhman Sharafi dari Western Sydney Universsity, Sydneny, Australia pada tahun 2016 yang berjudul " $A$ new model for bridge management: Part B: decision support system for remediation planning". Penelitian ini menghasilkan metodologi pendukung keputusan yang digerakkan oleh persyaratan untuk perbaikan jembatan beton Proses hierarki analitik yang disederhanakan digunakan sebagai teknik pengambilan keputusan multi-kriteria .

h. Penelitian yang dilakukan oleh Rubayet Karim, C. L Karmaker dari Jessore Universitas of Science and Technology, Bangladesh pada tahun 2016 yang berjudul "Machine Selection by AHP and TOPSIS Methods". Penelitian ini menghasilkan Sistem pendukung keputusan telah dikembangkan dalam proses evaluasi mesin Kerangka kerja ini akan bertindak sebagai panduan bagi pembuat keputusan untuk memilih mesin yang cocok melalui pendekatan terpadu AHP \& TOPSIS .

i. Penelitian yang dilakukan oleh R. K. Jaiswal. ThomasR. V. GalkateN. C. GhoshS. Singh dari National Institute of Hydrology Regional, India pada tahun 2014 yang berjudul “Watershed Prioritization Using Saaty's AHP Based Decision Support for Soil Conservation Measures". Penelitian ini menghasilkan proses hierarki analitik Saaty (SAHP) telah digunakan sebagai sistem pendukung keputusan untuk mengidentifikasi sub-DAS yang tertekan secara lingkungan .

j. Penelitian yang dilakukan oleh Slawomir Klos dari University of Zielona GóraZielona GóraPoland pada tahun 2015 yang berjudul "Implementation of the AHP Method in ERP-Based Decision Support Systems for a New Product Development". Penelitian ini menghasilkan Sistem pendukung keputusan yang didasarkan pada analisis faktor-faktor teknis dan bisnis dari produk-produk baru. Untuk mengotomatisasi proses pengambilan keputusan, data yang diperlukan untuk sistem pendukung keputusan harus diperoleh dari ERP (sistem sumber daya perusahaan). Sistem pendukung keputusan yang diusulkan didasarkan pada metode AHP. 


\section{METODE PENELITIAN}

1. Sebelum memulai penelitian terlebih dahulu mempelajari beberapa teori dan materi penelitian dengan cara melakukan riset pustaka dan dilanjutkan dengan penetapan alternatif dari kriteria.

2. Kemudian melakukan survei (Survey research) dengan cara membagikan kuesioner untuk pengumpulan data sampel dari beberapa kelompok pengguna Sistem Operasi untuk Email Server dengan menggunakan metode purposive sampling. Menurut Sugiyono ( 2016:85 ) Metode purposive sampling adalah teknik pengambilan sampel sumber data dengan pertimbangan tertentu. Sampling ini dipilih karena target responden diusahakan merupakan pihak yang mengerti tentang Sistem operasi untuk Email Server, walaupun pengertian tersebut dengan tingkat yang berbeda-beda dengan kelompok yang berbeda dengan jumlah 2 kelompok.

3. Metode yang digunakan dalam penelitian ini adalah metode penelitian Kuantitatif. Hal ini berdasarkan pada proses pengambilan data melalui proses pembobotan dan menggunakan metode AHP. Menurut Sugiyono ( 2016:8 ) Penelitian kuantitatif digunakan untuk meneliti pada populasi atau sampel tertentu, pengumpulan data menggunakan instrumen penelitian, analisis data, statistik dengan tujuan untuk menguji hipotesis yang telah ditetapkan. Penelitian dilakukan dengan membagi kuesioner kepada dua kelompok responden :

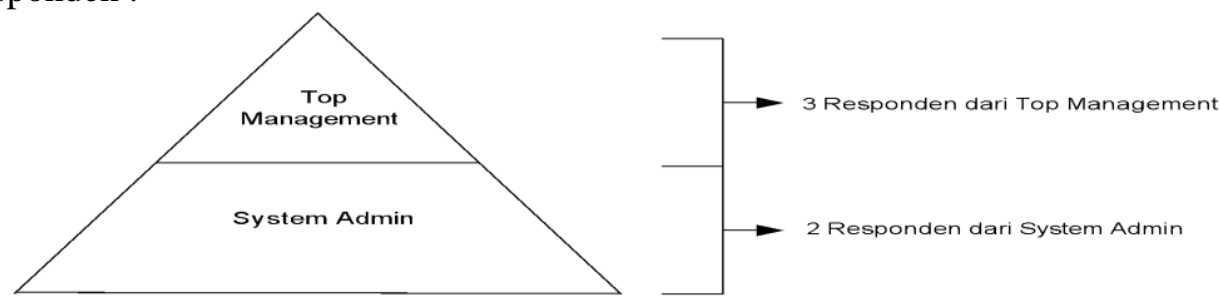

Gambar 1. Jenis Responden Penelitian

4. Pengumpulan data responden dilakukan dengan cara menyusun kuesioner dengan isi yang sesuai dengan kerangka pikiran penelitian, yang memuat kriteria pemecahan masalah dan alternatif solusi.

a. Pada bagian pertama kuesioner adalah pertanyaan-pertanyaan atas penilain responden pada kriteria, stabilitas, manageability, interoperabilitas, kemampuan beradaptasi, kemudahan pengembangan, keterjangkauan dan kemudahan.

b. Pada bagian kedua dari kuesioner merupakan pertanyaan atas penilaian responden pada alternatif solusi pemilihan sistem operasi untuk Email Server, yang terdiri dari tiga alternatif sistem operasi yaitu SUSE Enterprise, Windows 2008, Sun solaris. Kuesioner dibagikan kepada 5 orang responden ahli yang telah ditentukan sebelumnya sebagai sumber data penelitian.

5. Pengolahan data kuesioner ini bertujuan untuk mencari nilai rata-rata geometrik dengan menggunakan perangkat lunak Expert Choice 2000 yang digunakan dalam pemprosesan data dengan metode AHP. Berdasarkan hasil dari perhitungan tersebut maka didapatkan nilai bobot untuk setiap kriteria dan alternatif. Hasil akhir dari pengolahan data akan menemukan jawaban atas permasalahan yang dihadapi, yaitu menentukan kriteria mana yang paling berpengaruh dalam pemilihan sistem operasi E-mail Server dan mana yang merupakan alternatif terbaik dan paling sesuai dengan perusahaan. 


\section{HASIL DAN PEMBAHASAN}

\section{1. $\quad$ Sistem Penunjang Keputusan (Decision Support System)}

Menurut Permana (2015) Sistem pendukung keputusan (SPK) adalah sebuah sistem yang dapat membantu seseorang dalam mengambil keputusan dari berbagai jenis pilihan yang dilakukan secara akurat dan sesuai dengan sasaran yang diinginkan . Keberadaan sistem yang canggih dan sumber daya yang pintar pada akhiran nya harus dapat mendukung pihak manajemen dalam membuat keputusan yang tepat, cepat dan berguna bagi perusahaan. Di dalam Jurnal lainnya oleh Sembiring (2017), Sistem pendukung keputusan memiliki beberapa karakteristik sebagai berikut :

a. SPK ditujukan untuk membantu keputusan-keputusan yang kurang terstruktur dan umumnya dihadapi oleh para manajer yang berada di tingkat puncak.

b. SPK merupakan gabungan antara kumpulan model kualitatif dan kumpulan data.

c. SPK memiliki fasilitas interaktif yang dapat mempermudah hubungan antara manusia dengan komputer.

d. SPK bersifat luwes dan dapat menyesuaikan dengan perubahan yang terjadi.

\section{2. $\quad$ Sistem Operasi}

Menurut TATA Consultancy Services, sebuah perusahaan akan mempertimbangkan kriteria-kriteria dibawah ini dalam memilih sistem operasi:
a. Keandalan / Reliability
b. Keamanan / Security
c. Skalabilitas
d. Manageability
e. Interoperabilitas
f. Adaptasi
g. Kemudahan Pembangunan
h. Keterjangkauan
i. Kemudahan Penggunaan

\subsection{Analytical Hierarchy Process (AHP)}

Metode AHP Merupakan salah satu metode pengambilan keputusan yang menggunakan factor-faktor logika, intuisi, pengalaman, pengetahuan, emosi dan rasa untuk dioptimasi dalam suatu proses yang sistematis serta mampu membandingkan secara berpasangan hal-hal yang dapat maupun tidak dapat diraba, data kuantitatif maupun data kualitatif. Secara umum langkah penyusunan AHP sebagian berikut :
a. Penyusunan Hirarki
b. Penilaian Kriteria dan Alternatif
c. Penentuan Prioritas
d. Konsistensi Logis

Dalam metode Analytical Hieraschy Process (AHP) yang pertama kali dilakukan adalah dekomposisi sebuah masalah, dimana masalah-masalah dipecahkan menjadi beberapa bagian dengan level yang berbeda-beda.

Berikut adalah hasil dekomposisi dengan tujuan memilih sistem operasi untuk layanan E-mail server : 


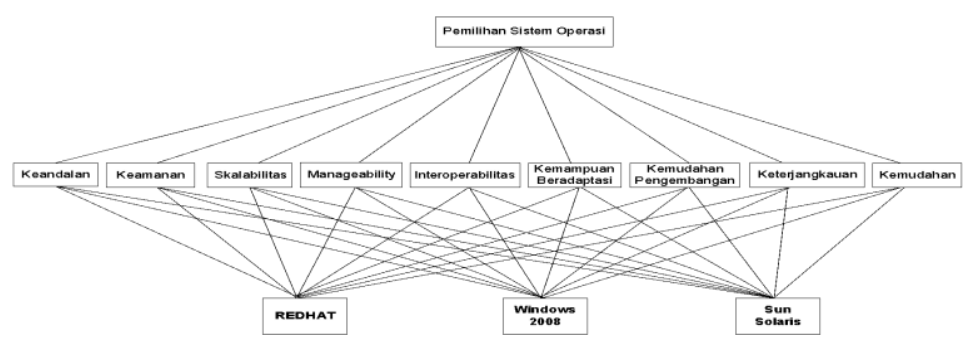

Gambar 2. Kerangka rancangan Pemilihan Alternatif

\subsection{Perbandingan Berpasangan kriteria}

Pengolahan data yang diambil dari kuesioner terhadap 5 orang responden. Kriteria berpasangan dilakukan sejumlah $\mathrm{n}$ dengan begitu dapat dihitung dengan $[(\mathrm{n}(\mathrm{n}-1)) / 2]$, dimana nilai $\mathrm{n}$ adalah banyaknya kriteria, jadi jumlah seluruh perbandingan kriteria yang dilakukan sebanyak :

Jumlah perbandingan berpasangan $=[(9(9-1)) / 2]=36$ kali

Berikut adalah tabel bentuk matriks pada penjumlahan kolom matriks kriteria dalam tabel 2

Tabel 1. Penjumlahan kolom Matriks kriteria

\begin{tabular}{|c|c|c|c|c|c|c|c|c|c|}
\hline & Keandalan & Keamanan & Skalabilitas & Manageability & Interoperabilitas & $\begin{array}{l}\text { Kemampuan } \\
\text { Beradaptasi }\end{array}$ & $\begin{array}{c}\text { Kemampuan } \\
\text { Pengembangan }\end{array}$ & Keterjangkauan & $\begin{array}{l}\text { Kemudahan } \\
\text { Penggunaan }\end{array}$ \\
\hline Keandalan & 1 & 0.52961 & 2.72407 & 0.57435 & 4.78176 & 2.37144 & 3.10369 & 2.55085 & 1.31951 \\
\hline Keamanan & 1.88817 & 1 & 4.18256 & 2.16894 & 1.97435 & 4.38433 & 2.63072 & 3.12913 & 2.16894 \\
\hline Skalabilitas & 0.36710 & 0.23909 & 1 & 0.65975 & 2.04767 & 1.36851 & 1.39765 & 1.74110 & 2.70192 \\
\hline Manageability & 1.74110 & 0.46105 & 1.51572 & 1 & 2.70192 & 1.74110 & 1.43097 & 1.64375 & 1.35096 \\
\hline Interoperabilitas & 0.20913 & 0.50650 & 0.48836 & 0.37011 & 1 & 2.04767 & 1.14870 & 1.97435 & 2.04767 \\
\hline Kemampuan Beradaptasi & 0.42168 & 0.22809 & 0.73072 & 0.57435 & 0.48836 & 1 & 2.49146 & 1.43097 & 0.94409 \\
\hline Kemampuan Pengembangan & 0.32220 & 0.38012 & 0.71549 & 0.69883 & 0.87055 & 0.40137 & 1 & 1.43097 & 0.94409 \\
\hline Keterjangkauan & 0.39203 & 0.31958 & 0.57435 & 0.60837 & 0.50650 & 0.69883 & 0.69883 & 1 & 0.80274 \\
\hline Kemudahan Penggunaan & 0.75786 & 0.46105 & 0.37011 & 0.74021 & 0.48836 & 1.05922 & 1.05922 & 1.24573 & 1 \\
\hline Jumlah & 7.099 & 4.125 & 12.301 & 7.395 & 14.859 & 15.072 & 14.961 & 16.147 & 13.280 \\
\hline
\end{tabular}

Untuk memastikan hasil jumlah perhitungan bobot kriteria dengan Expert Choice apakah sama dengan hasil perhitungan dengan manual. Dilakukan dengan menjumlahkan angka perbandingan berpasangan dalam seperti yang terlihat dalam table 2 . Contoh perhitungan bobot kriteria Skalabilitas :

$[(0.36710: 7.09926)+(0.23909: 4.12509)+(1: 12.30138)+(0.65975: 7.39490)+($ $2.04767: 14.85947)+(1.36851: 15.07247)+(1.39765: 14.96124)+(1.74110: 16.14685)$ $+(2.70192: 13.27992)] / 9=0.101$ atau $10.1 \%$

Berikut Urutan bobot kriteria berdasarkan prioritas kepentingan :

Tabel 2. Urutan bobot kriteria

\begin{tabular}{|l|l|l|}
\hline Urutan & Kriteria & Bobot \\
\hline 1 & Keamanan & $23.3 \%$ \\
\hline 2 & Keandalan & $16.7 \%$ \\
\hline 3 & Manageability & $13.7 \%$ \\
\hline 4 & Skalabilitas & $10.1 \%$ \\
\hline 5 & Interoperabilitas & $8.6 \%$ \\
\hline 6 & Kemudahan Penggunaan & $8.2 \%$ \\
\hline 7 & Kemampuan Beradaptasi & $7.3 \%$ \\
\hline 8 & Kemampuan Pengembangan & $6.6 \%$ \\
\hline 9 & Keterjangkauan & $5.5 \%$ \\
\hline Jumlah & & $\mathbf{1 0 0 \%}$ \\
\hline
\end{tabular}


Berdasarkan hasil perhitungan kuesioner yang disi oleh responden dapat disimpulkan bahwa kriteria keamanan merupakan kriteria yang paling penting $23.3 \%$ dibandingkan dengan yang lain.

\subsection{Hasil perbandingan berpasangan Alternatif berdasarkan Kriteria Kehandalan}

Tabel 3. Penjumlahan kolom Matriks Alternatif menurut kriteria Keandalan

\begin{tabular}{|l|l|l|l|}
\hline & Redhat & Windows 2008 & Sun Solaris \\
\hline Redhat & 1 & 2.70192 & 1.08447 \\
\hline Windows 2008 & 0.37011 & 1 & 0.60837 \\
\hline Sun Solaris & 0.92211 & 1.64375 & 1 \\
\hline Jumlah & 2.29222 & 5.34567 & 2.69284 \\
\hline
\end{tabular}

Contoh perhitungan bobot Alternatif Windows 2008 dengan kriteria keandalan :

$[(0.37011: 2,29222)+(1: 5.34567)+(0.60837: 2.69284)] / 3=0.191$ atau $19.1 \%$

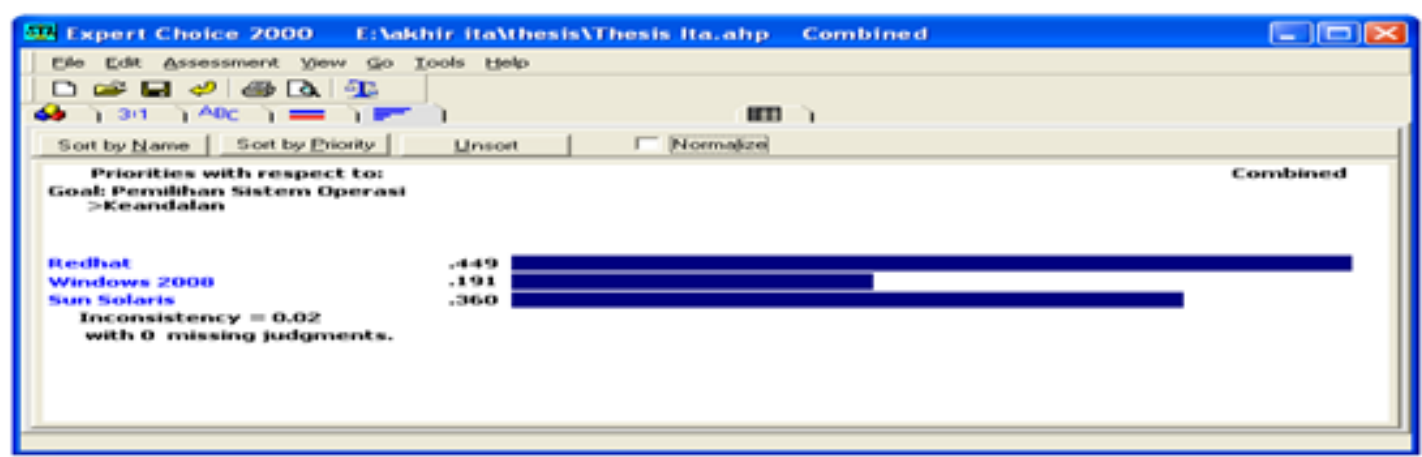

Gambar 3. Bobot Alternatif Menurut Kriteria Keandalan

Dari gambar 3. Bobot alternatif menurut kriteria keandalan, dapat diurutkan alternatif prioritas kepentingan pada kriteria keandalan dapat dilihat bahwa Redhat merupakan alternatif yang memiliki bobot paling tinggi dengan nilai $44.9 \%$.

\subsection{Hasil perbandingan berpasangan Alternatif berdasarkan Kriteria Keamanan}

Tabel 4. Penjumlahan kolom Matriks Alternatif menurut kriteria Keamanan

\begin{tabular}{|l|l|l|l|}
\hline & Redhat & Windows 2008 & Sun Solaris \\
\hline Redhat & 1 & 3.03143 & 1.58489 \\
\hline Windows 2008 & 0.32988 & 1 & 0.40137 \\
\hline Sun Solaris & 0.63096 & 2.49146 & 1 \\
\hline Jumlah & 1.96084 & 6.52289 & 2.98626 \\
\hline
\end{tabular}

Contoh perhitungan bobot Alternatif Redhat dengan kriteria keamanan :

$[(1: 1.96084)+(3.03143: 6.52289)+(1.58489: 2.98626)] / 3=0.502$ atau $50.2 \%$ 


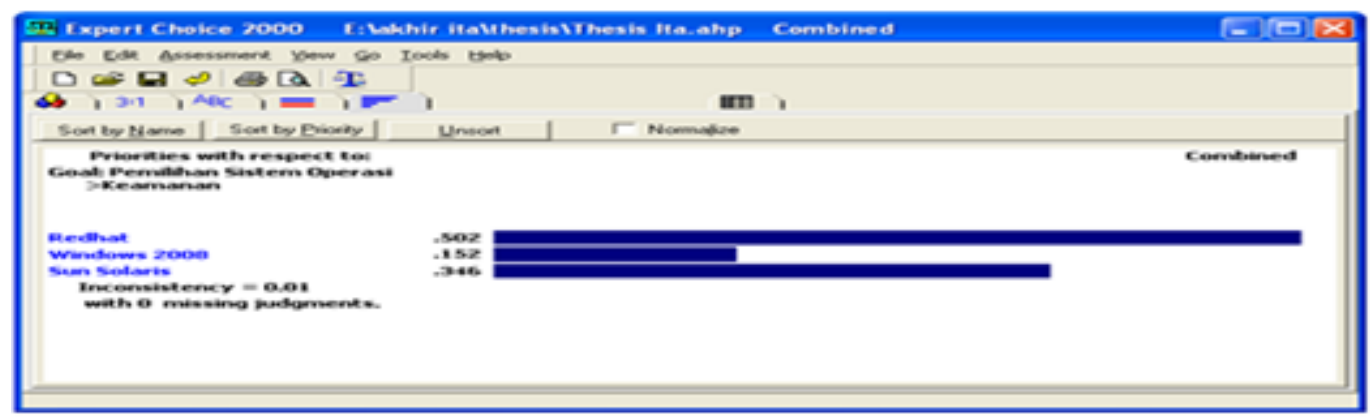

Gambar 4. Bobot Alternatif Menurut Kriteria Keamanan

Dari gambar 4. bobot alternatif menurut kriteria keamanan, dapat diurutkan alternatif prioritas kepentingan pada kriteria keamanan bahwa Redhat merupakan alternatif yang memiliki bobot paling tinggi dengan nilai $50.2 \%$.

\subsection{Hasil Perbandingan Berpasangan Alternatif Berdasarkan Kriteria Skalabilitas}

Tabel 5. Penjumlahan kolom Matriks Alternatif menurut kriteria Skalabilitas

\begin{tabular}{|l|l|l|l|}
\hline & Redhat & Windows 2008 & Sun Solaris \\
\hline Redhat & 1 & 0.75786 & 1.05922 \\
\hline Windows 2008 & 1.31951 & 1 & 1.0 \\
\hline Sun Solaris & 0.94409 & 1.0 & 1 \\
\hline Jumlah & 3.26360 & 2.75786 & 3.05922 \\
\hline
\end{tabular}

Contoh perhitungan bobot Alternatif Windows 2008 dengan kriteria skalabilitas :

$[(1.31951: 3.26360)+(1.0: 2.75786)+(1: 3.05922)] / 3=0.365$ atau $36.5 \%$

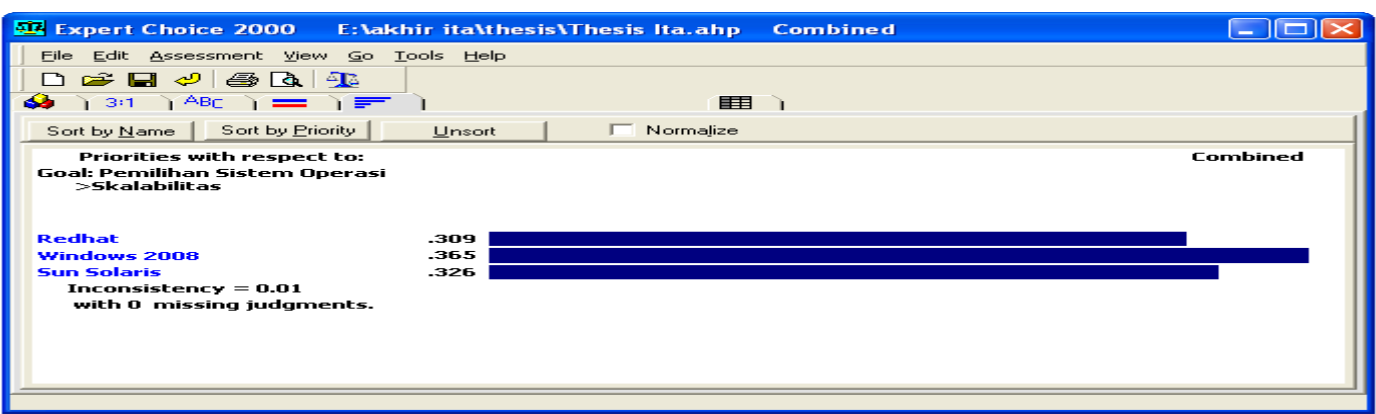

Gambar 5. Bobot Alternatif Menurut Kriteria Skalabilitas

Dari gambar 5. Bobot alternatif menurut kriteria skalabilitas, dapat diurutkan alternatif prioritas kepentingan pada kriteria skalabilitas dapat dilihat bahwa Windows 2008 merupakan alternatif yang memiliki bobot paling tinggi dengan nilai $36.5 \%$.

\subsection{Hasil perbandingan berpasangan Alternatif berdasarkan Kriteria Manageability}

Tabel 6. Penjumlahan kolom Matriks Alternatif menurut kriteria Manageability

\begin{tabular}{|l|l|l|l|}
\hline & Redhat & Windows 2008 & Sun Solaris \\
\hline Redhat & 1 & 3.06389 & 2.35216 \\
\hline Windows 2008 & 0.32638 & 1 & 0.75786 \\
\hline Sun Solaris & 0.42514 & 1.31951 & 1 \\
\hline Jumlah & 1.75152 & 5.38340 & 4.11002 \\
\hline
\end{tabular}


Contoh perhitungan bobot Alternatif Redhat dengan kriteria Manageability:

$[(1: 1.75152)+(3.06389: 5.38340)+(2.35216: 4.11002)] / 3=0.571$ atau $57.1 \%$

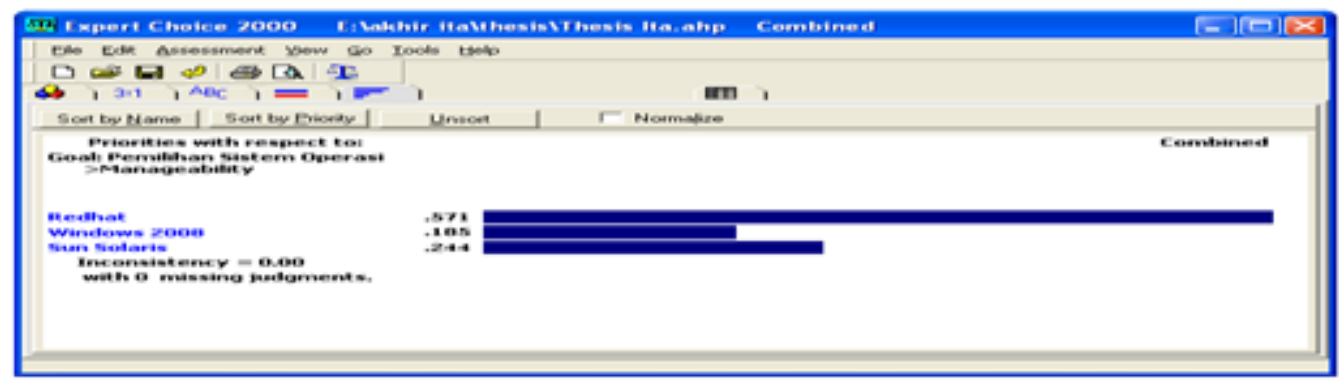

Gambar 6. Bobot Alternatif Menurut Kriteria Manageability

Dari gambar 6. bobot alternatif menurut kriteria manageability, dapat diurutkan alternatif prioritas kepentingan pada kriteria manageability dapat dilihat bahwa Redhat merupakan alternatif yang memiliki bobot paling tinggi dengan nilai $57.1 \%$.

\subsection{Hasil perbandingan berpasangan Alternatif berdasarkan kriteria Interoperabilitas}

Tabel 7. Penjumlahan kolom Matriks Alternatif menurut kriteria Interoperasibilitas

\begin{tabular}{|l|l|l|l|}
\hline & Redhat & Windows 2008 & Sun Solaris \\
\hline Redhat & 1 & 0.39203 & 0.75786 \\
\hline Windows 2008 & 2.55085 & 1 & 1.21673 \\
\hline Sun Solaris & 1.31951 & 0.82188 & 1 \\
\hline Jumlah & 4.87036 & 2.21390 & 2.97459 \\
\hline
\end{tabular}

Contoh perhitungan bobot Alternatif Sun solaris dengan kriteria interoperasibilitas :

$[(1.31951: 4.87036)+(0.82188: 2.21390)+(1: 2.97459)] / 3=0.326$ atau $32.6 \%$

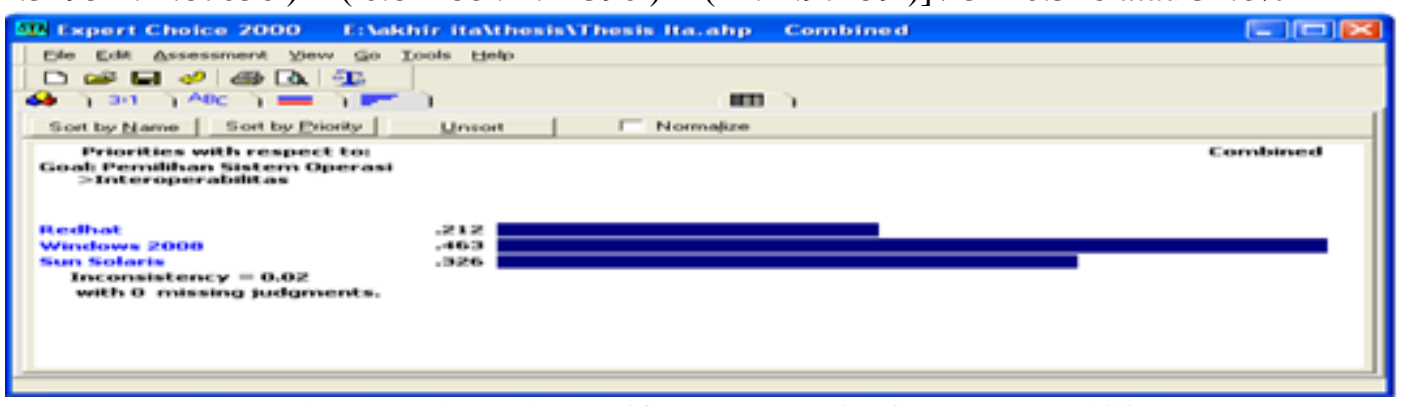

Gambar 7. Bobot Alternatif Menurut Kriteria Interoperabilitas

Dari gambar 7. bobot alternatif menurut kriteria interoperabilitas, dapat diurutkan alternatif prioritas kepentingan pada kriteria interoperabilitas dapat dilihat bahwa Windows 2008 merupakan alternatif yang memiliki bobot paling tinggi dengan nilai $46.3 \%$.

\subsection{Hasil perbandingan berpasangan Alternatif berdasarkan Kriteria Kemampuan} beradaptasi

Tabel 8. Penjumlahan kolom Matriks Alternatif menurut kriteria Kemampuan Beradaptasi

\begin{tabular}{|l|l|l|l|}
\hline & Redhat & Windows 2008 & Sun Solaris \\
\hline Redhat & 1 & 2.09128 & 4.04282 \\
\hline Windows 2008 & 0.47818 & 1 & 1.88818 \\
\hline Sun Solaris & 0.24735 & 0.52961 & 1 \\
\hline Jumlah & 1.72553 & 3.62089 & 6.93100 \\
\hline
\end{tabular}


Contoh perhitungan bobot Alternatif Sun solaris dengan kriteria kemampuan beradaptasi :

$[(0.47818: 1.72553)+(1: 3.62089)+(1.88818: 6.93100)] / 3=0.275$ atau $27.5 \%$

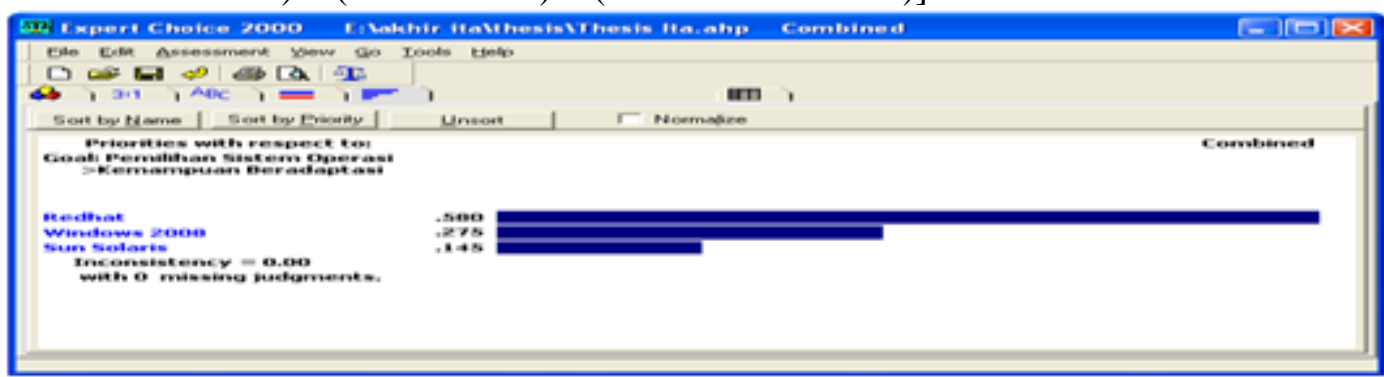

Gambar 8. Bobot Alternatif Menurut Kriteria Kemampuan beradaptasi

Dari gambar 8. bobot alternatif menurut kriteria kemampuan beradaptasi, dapat diurutkan alternatif prioritas kepentingan pada kriteria kemampuan beradaptasi dapat dilihat bahwa Redhat merupakan alternatif yang memiliki bobot paling tinggi dengan nilai $58 \%$.

\subsection{Hasil perbandingan berpasangan Alternatif berdasarkan kriteria Kemudahan Pengembangan}

Tabel 9. Penjumlahan kolom Matriks Alternatif menurut kriteria Kemudahan Pengembangan

\begin{tabular}{|l|l|l|l|}
\hline & Redhat & Windows 2008 & Sun Solaris \\
\hline Redhat & 1 & 2.55085 & 2.49146 \\
\hline Windows 2008 & 0.39203 & 1 & 1.20112 \\
\hline Sun Solaris & 0.40137 & 0.83256 & 1 \\
\hline Jumlah & 1.79340 & 4.38341 & 4.69258 \\
\hline
\end{tabular}

Contoh perhitungan bobot Alternatif Windows 2008 dengan kriteria Kemudahan pengembangan $:[(0.39203: 1.79340)+(1: 4.38341)+(1.20112: 4.69258)] / 3=0.234$ atau $23.4 \%$

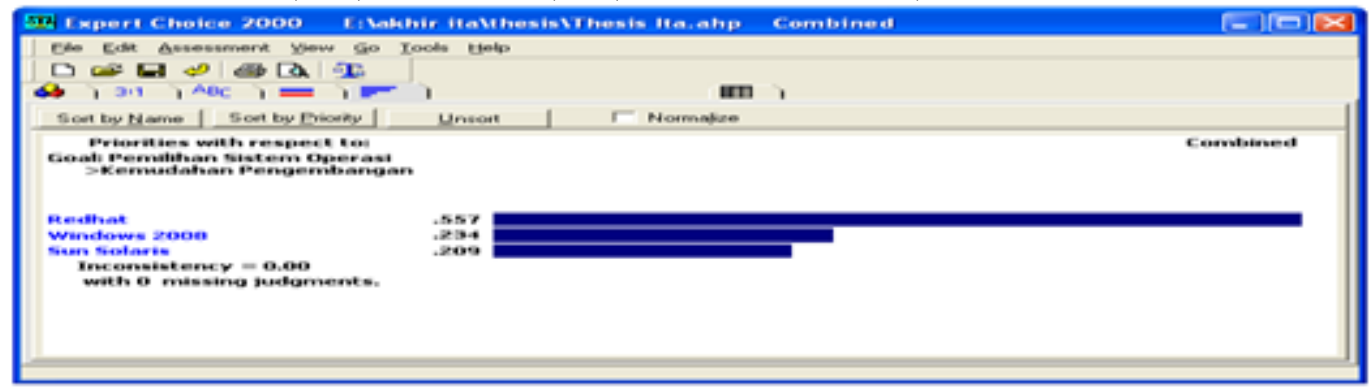

Gambar 9. Bobot Alternatif Menurut Kriteria Kemudahan Pengembangan

Dari gambar 9. bobot alternatif menurut kriteria kemudahan pengembangan, dapat diurutkan alternatif prioritas kepentingan pada kriteria kemudahan pengembangan dapat dilihat bahwa Redhat merupakan alternatif yang memiliki bobot paling tinggi dengan nilai $55.7 \%$.

\subsection{Hasil perbandingan berpasangan Alternatif berdasarkan kriteria Keterjangkauan}

Tabel 10. Penjumlahan kolom Matriks Alternatif menurut kriteria Keterjangkauan

\begin{tabular}{|l|l|l|l|}
\hline & Redhat & Windows 2008 & Sun Solaris \\
\hline Redhat & 1 & 3.3227 & 3.9487 \\
\hline Windows 2008 & 0.30096 & 1 & 1.7411 \\
\hline Sun Solaris & 0.25325 & 0.57435 & 1 \\
\hline Jumlah & 1.55421 & 4.89705 & 6.68980 \\
\hline
\end{tabular}


Contoh perhitungan bobot Alternatif Windows 2008 dengan kriteria Kemudahan pengembangan $:[(0.30096: 1.55421)+(1: 4.89705)+(1.7411: 6.68980)] / 3=0.218$ atau $21.8 \%$

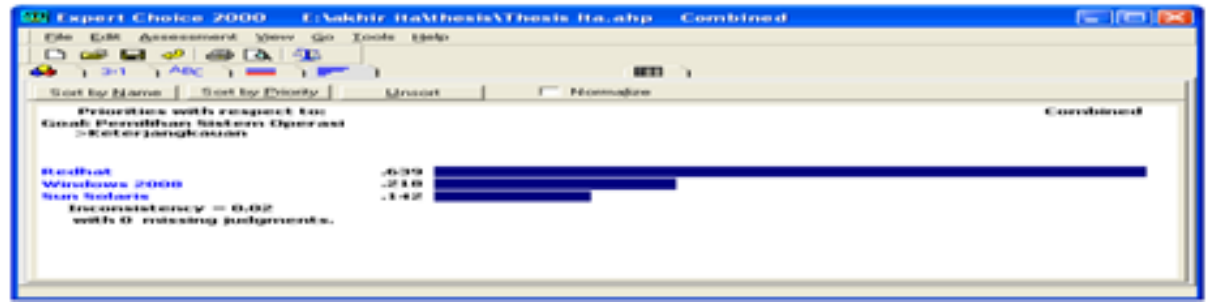

Gambar 10. Bobot Alternatif Menurut Kriteria Keterjangkauan

Dari gambar 10. bobot alternatif menurut kriteria keterjangkauan, dapat diurutkan alternatif prioritas kepentingan pada kriteria keterjangkauan dapat dilihat bahwa Redhat merupakan alternatif yang memiliki bobot paling tinggi dengan nilai $63.9 \%$.

\subsection{Hasil perbandingan berpasangan Alternatif berdasarkan kriteria Kemudahan penggunaan}

Tabel 11. Penjumlahan kolom Matriks Alternatif menurut kriteria Kemudahan Penggunaan

\begin{tabular}{|l|l|l|l|}
\hline & Redhat & Windows 2008 & Sun Solaris \\
\hline Redhat & 1 & 0.37011 & 0.65975 \\
\hline Windows 2008 & 2.70192 & 1 & 1.43097 \\
\hline Sun Solaris & 1.51572 & 0.69883 & 1 \\
\hline Jumlah & 5.21764 & 2.06893 & 3.09072 \\
\hline
\end{tabular}

Contoh perhitungan bobot Alternatif Windows 2008 dengan kriteria kemudahan penggunaan : $[(2.70192: 5.21764)+(1: 2.06893)+(1.43097: 3.09072)] / 3=0.488$ atau $48.8 \%$

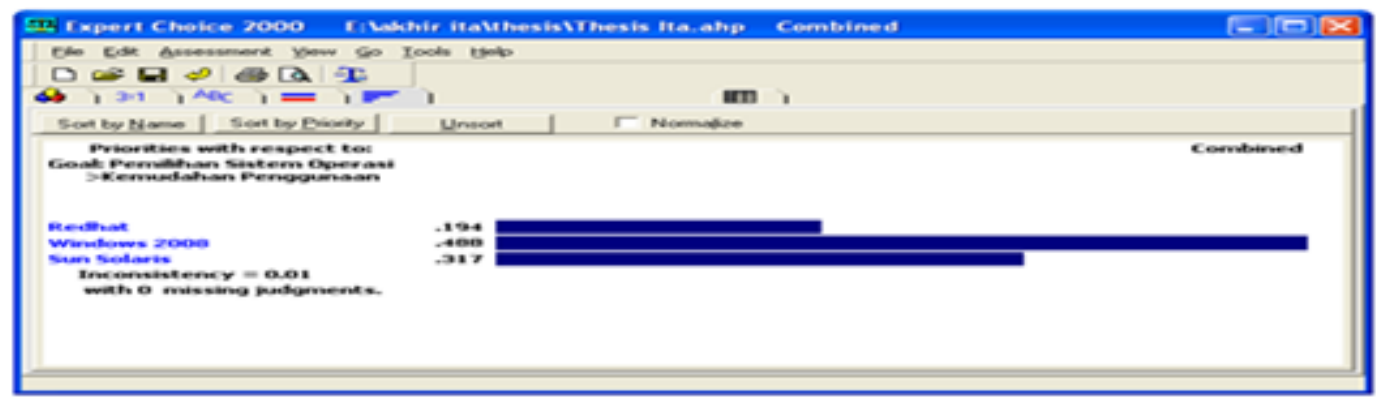

Gambar 11. Bobot Alternatif Menurut Kriteria Kemudahan Penggunaan

Dari gambar 11 bobot alternatif menurut kriteria kemudahan penggunaan, dapat diurutkan alternatif prioritas kepentingan pada kriteria kemudahan penggunaan dan dapat dilihat bahwa Windows 2008 merupakan alternatif yang memiliki bobot paling tinggi dengan nilai $48.8 \%$.

\subsection{Rasio Inkonsistensi (Inconsistency Ration)}

Tahap selanjutnya adalah menghitung rasio inkonsisten (Inconsistency ration). Penghitungan ini dilakukan untuk memastikan apakah perbandingan berpasangan telah dilakukan dengan konsisten atau tidak. Jika nilai Consistency Ration (CR) kurang dari 0,1 (10\%) maka Penilaian rasio inkonsistensi dikatakan baik. 
Tabel 12. Perbandingan Jumlah Bobot kolom dengan Bobot Kriteria :

\begin{tabular}{|l|l|l|l|}
\hline No & Kriteria & Penjumlahan kolom & Bobot Kriteria \\
\hline 1 & Keandalan & 7.09926 & 0.167 \\
\hline 2 & Keamanan & 4.12509 & 0.233 \\
\hline 3 & Skalabilitas & 12.30138 & 0.101 \\
\hline 4 & Manageability & 7.39490 & 0.137 \\
\hline 5 & Interoperabilitas & 14.85947 & 0.086 \\
\hline 6 & Kemampuan Beradaptasi & 15.07247 & 0.073 \\
\hline 7 & Kemampuan Pengembangan & 14.96124 & 0.066 \\
\hline 8 & Keterjangkauan & 16.14685 & 0.055 \\
\hline 9 & Kemudahan Penggunaan & 13.27992 & 0.082 \\
\hline
\end{tabular}

$\lambda \max$

$$
\begin{aligned}
& =\sum\left(\sum \text { kolom } \times \text { bobot kriteria }\right) \\
& =(7.09926 \times 0.167)+(4.12509 \times 0.233)+(12.301138 \times 0.101) \\
& =+(7.39490 \times 0.137)+(14.85947 \times 0.086)+(15.07247 \times 0.073) \\
& =+(14.96124 \times 0.066)+(16.14685 \times 0.055)+(13.27992 \times 0.082) \\
& =9.7449 \text { ataub } 9.745
\end{aligned}
$$

Penghitungan Consistency Index ( CI )

$$
\begin{array}{ll}
\mathrm{CI} & =(\lambda \max -\mathrm{n}) /(\mathrm{n}-1) \quad \text { nilai “ } \mathrm{n} \text { " adalah jumlah kriteria } \\
& =(9.745-9) /(9-1)=0.0931 \\
\text { Penghitungan CR } & \\
\mathrm{CR} & =\mathrm{CI} / \mathrm{RI} \\
& =0.0931 / 1.45 \\
& =0.061 \text { atau } 6.1 \%
\end{array}
$$

Setelah perhitungan nilai CR masih dibawah 10\%, maka keputusan hasil jawaban responden merupakan keputusan yang konsisten. Dengan begitu data rasio inkonsistensi yang didapat berdasarkan hasil pengolahan data responden dengan menggunakan expert choice 2000 dapat dilihat pada tabel dibawah ini :

Tabel 13. Rasio Inkonsistensi

\begin{tabular}{|l|l|l|}
\hline No & Kriteria & Penjumlahan kolom \\
\hline 1 & Goal : Pemilihan Sistem Operasi & 0.07 \\
\hline 2 & Alternatif - kriteria Keandalan & 0.02 \\
\hline 3 & Alternatif - kriteria Keamanan & 0.01 \\
\hline 4 & Alternatif - kriteria Skalabilitas & 0.01 \\
\hline 5 & Alternatif - kriteria Manageability & 0.00 \\
\hline 6 & Alternatif - kriteria Interoperabilitas & 0.02 \\
\hline 7 & Alternatif - kriteria Kemampuan Beradaptasi & 0.00 \\
\hline 8 & Alternatif - kriteria Kemampuan Pengembangan & 0.00 \\
\hline 9 & Alternatif - kriteria Keterjangkauan & 0.02 \\
\hline 10 & Alternatif - kriteria Kemudahan Penggunaan & 0.01 \\
\hline
\end{tabular}

Jika dilihat dari tabel rasio inkonsisten pada tabel 14. bahwa seluruh nilai berada dibawah 01.1 (10\%), dengan begitu dapat disimpulkan hasil penelitian ini menunjukan bahwa jawaban yang diberikan responden adalah jawaban - jawaban yang menunjukan kekonsistenan untuk hampir semua pertanyaan.

\subsection{Bobot Keseluruhan Berdasarkan Kriteria dan Alternatif}

Dalam tahapan ini adalah perhitungan secara keseluruhan dari setiap data responden yang diwakili dengan nama P2,P3,P4,P5 dan P6. Data tersebut diolah dengan Expert Choice 
yang menghasilkan bobot perhitungan secara keseluruhan. Seperti yang terlihat pada gambar di bawah ini.

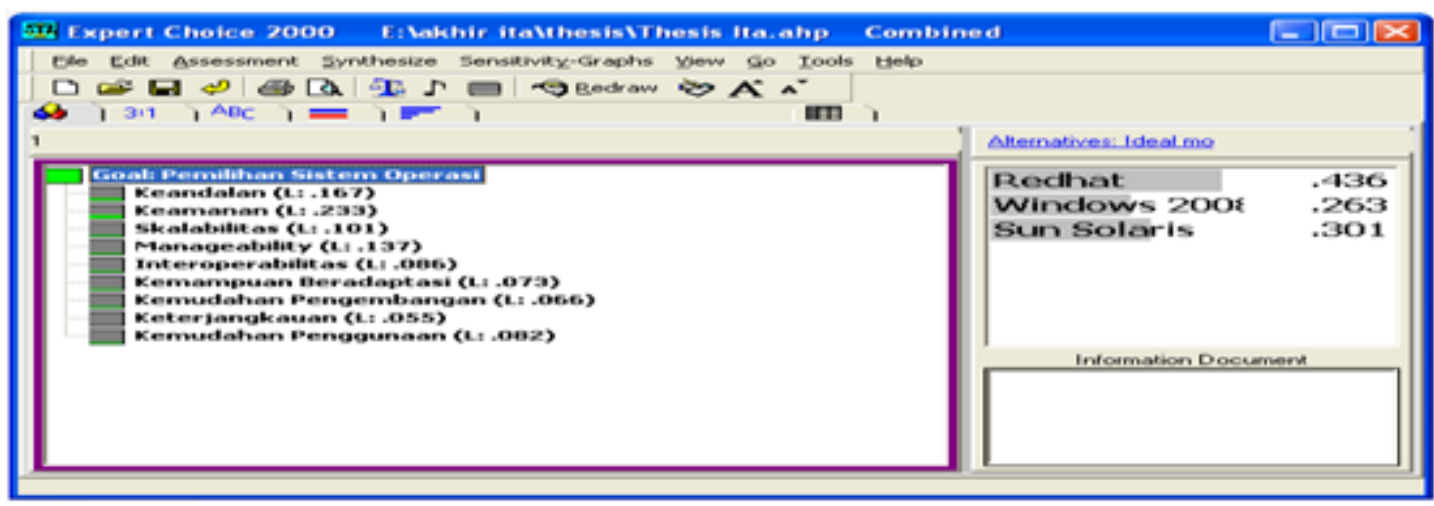

Gambar 12. Bobot Keseluruhan

Tabel 14. Bobot keseluruhan pemilihan sistem operasi

\begin{tabular}{|l|l|l|l|}
\hline Level & Elemen & Prioritas & Bobot \\
\hline \multirow{4}{*}{ Alternatif } & Redhat & 1 & 0.436 \\
\cline { 2 - 4 } & Sun Solaris & 2 & 0.263 \\
\cline { 2 - 4 } & Windows 2008 & 3 & 0.301 \\
\hline \multirow{5}{*}{ Kriteria } & Keamanan & 1 & 0.233 \\
\cline { 2 - 4 } & Keandalan & 2 & 0.167 \\
\cline { 2 - 4 } & Manageability & 3 & 0.137 \\
\cline { 2 - 4 } & Skalabilitas & 4 & 0.101 \\
\cline { 2 - 4 } & Interoperabilitas & 5 & 0.086 \\
\cline { 2 - 4 } & Kemudahan Penggunaan & 6 & 0.082 \\
\cline { 2 - 4 } & Kemampuan Beradaptasi & 7 & 0.073 \\
\cline { 2 - 4 } & Kemampuan Pengembangan & 8 & 0.066 \\
\cline { 2 - 4 } & Keterjangkauan & 9 & 0.055 \\
\hline
\end{tabular}

Dari hasil penelitian ini telah didapat bahwa kriteria yang dianggap paling penting adalah kriteria keamanan karena responden menginginkan sebuah sistem operasi yang aman yang tidak dengan mudah diserang virus atau program yang tidak seharusnya bekerja didalam server email yang akan digunakan untuk layanan email customer. Untuk alternatif sebagian besar responden memilih Redhat yang merupakan salah satu produk dari linux yang sudah terkenal dengan kualitas keamanan dan kehandalannya di dunia sistem operasi.

\section{KESIMPULAN}

Dari uraian pembahasan sebelumnya maka kesimpulan dari penelitian ini adalah sebagai berikut:

1. Dengan banyaknya sistem operasi yang beredar dipasaran dan tidak adanya kriteria yang tepat untuk membuat keputusan membuat bagian operasional khususnya kepala bagian operasional sulit menentukan sistem operasi yang tepat untuk email server customer. Maka hal yang harus dilakukan oleh Bagian operasional adalah menentukan sistem operasi yang akan dijadikan alternatif untuk layanan E-mail server.

2. Metode yang digunakan dalam penelitian ini adalah metode penelitian Kuantitatif. Hal ini berdasarkan pada proses pengambilan data melalui proses pembobotan dan menggunakan metode AHP. 
3. Hasil akhir dari pengolahan data dengan perangkat lunak Expert Choice 2000 akan menemukan jawaban atas permasalahan yang dihadapi, yaitu menentukan kriteria mana yang paling berpengaruh dalam pemilihan sistem operasi E-mail Server dan mana yang merupakan alternatif terbaik dan paling sesuai dengan perusahaan.

4. Kriteria yang dianggap paling penting adalah kriteria keamanan karena responden menginginkan sebuah sistem operasi yang aman dan tidak dengan mudah diserang virus atau program yang tidak seharusnya bekerja didalam server email yang akan digunakan untuk layanan email customer.

5. Untuk alternatif sebagian besar responden memilih Redhat yang merupakan salah satu produk dari linux yang sudah terkenal dengan kualitas keamanan dan kehandalannya di dunia sistem operasi.

6. Dengan digunakannya sistem ini maka proses pembuatan keputusan akan lebih mudah karena dibantu dengan kriteria yang tepat berdasarkan responden ahli dalam bidangnya akan memberikan rekomendasi dan pertimbangan sehingga antara manfaat dan investasi yang keluar akan sebanding.

\section{SARAN}

Berdasarkan pembahasan tentang implementasi sistem ini, dapat disampaikan beberapa saran untuk digunakan pada penelitian selanjutnya:

1. Dengan menggunakan sistem penunjang keputusan berbasis AHP dapat dilakukan pengembangan lebih lanjut yang sesuai karena dapat menggunakan beberapa kriteria dalam proses penunjang keputusan.

2. Hasil implementasi sistem penunjang keputusan berbasis AHP memberikan nilai tambah yang tinggi melalui ROI ( Return on Invesment ) atas pembelian / pengadaan produk sistem operasi sehingga antara manfaat dan investasi yang keluar akan sebanding.

\section{DAFTAR PUSTAKA}

[1] Sarwindah \& Elly Yanuarti. (2018). Sistem Penunjang Keputusan Pemilihan Perumahan Subsidi Berdasarkan Kebutuhan Konsumen dengan metode AHP. Konferensi Nasional Sistem Informasi 2018 STMIK Atma Luhur Pangkalpinang.

[2] Umar, Rusydi ., Fadlil, Abdul \& Yuminah. (2018). Sistem Pendukung Keputusan dengan Metode AHP untuk Penilaian Kompetensi Soft Skill Karyawan. Yogyakarta, Jurnal Ilmu Komputer dan Informatika, Vol. 4 No. 1.

[3] Yusnitha, Karmila., Tursina \& Muhammad Azhar Irwansyah. (2019). Sistem Pendukung Keputusan Pemilihan Wilayah Prioritas Intervensi Kegiatan Keluarga Berencana dengan Metode AHP-SMART. Kalimantan Barat, Jurnal Edukasi dan Penelitian Informatika, Vol. 5 No. 1.

[4] Harli, Eko. 2016. Pemilihan Network Monitoring System Berdasarkan Kajian Efektifitas Sistem Informasi dengan Pendekatan AHP: Studi Kasus pada -PT.TUV. Jurnal Edukasi dan Penelitian Informatika (JEPIN). Vol. 2 : 64-70.

[5] Prihartono, Yogi dan Hilyah Magdalena. 2016. Penerapan Metode Analytical Hierarchy Process (AHP) Sebagai Pendukung Keputusan dalam Menentukan Internet Service Provider Terbaik di Pangkalpinang. Jurnal SISFOKOM, Volume 05, Nomor 01. 
[6] Madyatmadja, Evaristus Didik. 2014. Decision Support System Model To Assist Management Consultant In Determining The Physical Infrastructure Fund. Journal of Theoretical and Applied Information Technology. Vol. 62 No.1.

[7] Rashidi, Maria, Bijan Samali \&Pezhman Sharafi. 2016. A new model for bridge management: Part B: decision support system for remediation planning. Australian Journal of Civil Engineering. Volume 14.

[8] Karim, Rubayet., C. L Karmaker. 2016. Machine Selection by AHP and TOPSIS Methods. American Journal of Industrial Engineering, Vol. 4, No. 1, 7-13.

[9] R. K. Jaiswal. ThomasR. V. GalkateN. C. GhoshS. Singh. 2014. Watershed Prioritization Using Saaty's AHP Based Decision Support for Soil Conservation Measures. WaterResources Management, Volume 28, Issue 2, pp 475-494.

[10] Klos, Slawomir. 2015. Implementation of the AHP Method in ERP-Based Decision Support Systems for a New Product Development. International Conference on Information and Software Technologies (ICIST ): Information and Software Technologies pp 199-207.

[11] Sugiyono. (2016). Metode Penelitian Kuantitatif, Kualitatif, dan R\&D. Alfabeta, CV. Bandung

[12] Permana, S. D. H. (2015). Sistem Penunjang Keputusan Pemilihan Sekolah Menengah Kejuruan Teknik Komputer Dan Jaringan Yang Terfavorit Dengan Menggunakan Multi-Criteria Decision Making. Jurnal Teknologi Informasi dan Ilmu Komputer, 2(1), 11-19.

[13] Sembiring, M. A. (2017). Penerapan Metode Simple Additive Weighting Sebagai Strategi Pembinaan Kecerdasan Anak. JURTEKSI, 4(1), 65-70. 